"Identifying the need and potential of ecotourism in Nainital, India"

\begin{tabular}{|c|c|c|}
\hline AUTHORS & \multicolumn{2}{|l|}{$\begin{array}{l}\text { Ramdas Lad (iD) } \\
\text { R }\end{array}$} \\
\hline ARTICLE INFO & \multicolumn{2}{|c|}{$\begin{array}{l}\text { Ramdas Lad (2020). Identifying the need and potential of ecotourism in Nainital, } \\
\text { India. Tourism and Travelling, 3(1), 3-15. doi:10.21511/tt.3(1).2021.02 }\end{array}$} \\
\hline DOI & \multicolumn{2}{|c|}{ http://dx.doi.org/10.21511/tt.3(1).2021.02 } \\
\hline RELEASED ON & \multicolumn{2}{|l|}{ Monday, 17 May 2021} \\
\hline RECEIVED ON & \multicolumn{2}{|l|}{ Tuesday, 16 February 2021} \\
\hline ACCEPTED ON & \multicolumn{2}{|l|}{ Friday, 07 May 2021} \\
\hline & \multicolumn{2}{|c|}{ 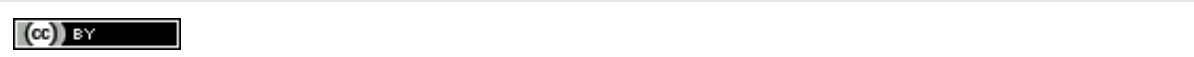 } \\
\hline LICENSE & \multicolumn{2}{|c|}{$\begin{array}{l}\text { This work is licensed under a Creative Commons Attribution } 4.0 \text { International } \\
\text { License }\end{array}$} \\
\hline JOURNAL & \multicolumn{2}{|l|}{ "Tourism and Travelling" } \\
\hline ISSN PRINT & \multicolumn{2}{|l|}{$2544-2295$} \\
\hline ISSN ONLINE & \multicolumn{2}{|l|}{$2616-5090$} \\
\hline PUBLISHER & \multicolumn{2}{|c|}{ LLC "Consulting Publishing Company "Business Perspectives" } \\
\hline FOUNDER & \multicolumn{2}{|c|}{ Sp. z o.o. Kozmenko Science Publishing } \\
\hline & & $\begin{array}{l}=-- \\
= \pm=-\end{array}$ \\
\hline NUMBER OF REFERENCES & NUMBER OF FIGURES & NUMBER OF TABLES \\
\hline 31 & 2 & 6 \\
\hline
\end{tabular}

(C) The author(s) 2023. This publication is an open access article. 


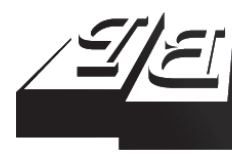

BUSINESS PERSPECTIVES

()

LLC "CPC "Business Perspectives" Hryhorii Skovoroda lane, 10, Sumy, 40022, Ukraine www.businessperspectives.org

Received on: $16^{\text {th }}$ of February, 2021

Accepted on: $7^{\text {th }}$ of May, 2021

Published on: $17^{\text {th }}$ of May, 2021

(๑) Ramdas Lad, 2021

Ramdas Lad, Assistant Professor of Commerce, PDEA's Prof. Ramkrishna More ACS College Akurdi, Savitribai Phule Pune University, Pune, Maharashtra, India.

\title{
IDENTIFYING THE NEED AND POTENTIAL OF ECOTOURISM IN NAINITAL, INDIA
}

\begin{abstract}
Nainital is a famous tourist destination of India, attracting hundreds of both domestic and foreign tourists every year. Some of the important places in the district are Nainital City, Hanumangarhi, Haldwani, Kaladhungi, Ramnagar, Bhowali, Ramgarh, Mukteshwar, Bhimtal, Sattal and Naukuchiatal. However, Nainital also faces an unsure future, near-stripped of its natural heritage, invaded by vested interests. Moreover, it is converting into concrete jungles.
\end{abstract}

There is an urgent need to embrace conservation of natural resources and to conserve and cherish the value of local traditions, customs and cultural heritage. Thus, ecotourism has a huge potential to attract tourists to Uttarakhand State without destroying or degrading the natural or cultural assets that the visitor has come to see.

The primary data was collected using questioners filled mainly by tourists, chief executives, senior managers, mangers and other staff of the organizations. Statistical tools were used to analyze data. In addition, secondary data was taken from the various journals, books and research papers.

It was revealed that ecotourism would provide employment and business opportunities to trained individuals of the state. Accordingly, conservation management and tourism activities may provide equitable, social and cultural benefits to men and women of Nainital community through education, training and creation of full time employment opportunities.

Keywords

JEL Classification

\section{INTRODUCTION}

Ecotourism is one of the fastest-growing areas of tourism, which have attracted lots of debate all over the world. Ecotourism involves visiting the places that are close to nature without disturbing flora and fauna of that region. Its main purpose is to create awareness among the tourist about the ecological conservation, which ensures regional and economic development along with preservation of the environment.

Robinson (1992) conducted a survey at Khumbu area of Nepal, which revealed that ecotourism affected material quality of life of the local communities, but it also resulted in loss of traditional employment system, acculturation and social disruption.

Thus, in the present scenario, a strive for economic development and ecology and ecosystem has been partaken. With an ideology of generating funds, the ways of revenue generation were hindered for the budding civilizations. Now, the need of the hour is to protect and conserve flora and fauna, and save this planet from disasters. With this framework and intention, the aim of this research concentrates around economic development. Hence, the aim must be "develop with degradation." 
Therefore, this philosophy must be imbibed in the policy in which it is strived for environmental protection, as well as economic development. This facet of development is termed eco-development. With such type of development, it is possible to reduce deforestation of landslides, contamination of water and de-urbanization. By this, it is possible to conserve our environment. Some of the segments of ecotourism are called rural tourism, adventure tourism, sports tourism, green tourism, cultural tourism, nature-oriented tourism, agro-tourism, health tourism. Hence, tourism with ecological safety or tourism with ecological conservation is termed as ecotourism.

The characteristics of ecotourism involve traveling to undisturbed natural areas with minimal impact on the environment. Additionally, it enhances the heritage and living cultures of host communities, promote sustainable use of biodiversity, providing jobs to local populations, helps in sustainable development of the region. Conservation of biological diversity and cultural diversity through ecosystem protection is also crucial. Ecotourism responsibly conserves the environment, sustains the well-being of local people and provides financial benefits and empowerment for local people.

Sharing this knowledge, local communities and indigenous people can obtain socio-economic benefits, as they announce their consent and participate in management of ecotourism activities.

An integral part of ecotourism is the promotion of recycling, energy efficiency, water conservation, and creation of economic opportunities for local communities.

\section{LITERATURE REVIEW}

Singh (2018) focused on sustainable development of tourism in Uttarakhand State to form tourist circuits. Additionally, he determined problems and put forward suitable suggestions for sustainable tourism development in Uttarakhand State. This type of sustainable tourism, oriented towards the viability of tourism industry, is referred to as the 'economic sustainability of tourism' or 'tourism imperative'. Sustainable tourism can be taken in four different interpretations, including economic sustainability of tourism, ecologically sustainable tourism, sustainable tourism development with focus both on environment and industry feasibility, and eventually tourism as a part of a strategy for sustainable development. The principles of sustainable development focus on long-term and more cautious approach to development, which ensures that the children can enjoy a quality life. Sati (2013) noticed that tourism has not only enhanced the economy and society of the state, but also has a negative impact on the environment. The mainland of Uttarakhand is more prone to natural hazards and environmental degradation. Tourism has further accelerated its intensity. Tourism within the Uttarakhand Himalaya encompasses a long tradition. However, the recent dawn of tourism, induced by the extension of modern transportation deep in- to the region, has had serious consequences for the local economy, ecology and society.

Saraswati and Ram (2017) highlighted that the most backward regions of Kumaon Division offer the most exotic resource base for tourism promotion. In modern scenario, only few of the destinations were highlighted. The study showed that these destinations have become overcrowded and all types of scarcities have emerged. Tourism can play a positive role in sustainable socio-economic development of these destinations from hill towns of the Himalayan to Sub-Himalayan region by providing resource planning and sustainable management. The Kumaon Division of Uttarakhand State offers many opportunities that have remained unexplored and subsequently unexploited. This can be overcome by strategically sustainable destination planning, development and marketing. In addition, the Tourism Department, Government of Uttarakhand, needs to elaborate better-focused promotional strategies and provision of suitable infrastructure facilities to address these problems. Lastly, it was suggested that there is a need to promote tourism whether it is of environmental, cultural, adventure or other interests. Tamta (2016) determined positive impact of seasonality in peak season of tourism in the selected areas, as it results in short term employments of local people during 
the peak season. The increasing tourism activities play an important role in the economy of selected town and act as a catalyst for the growth and development of local economy, as well as local market for the local people and tourists. Due to tourism activities, local area has developed basic tourism infrastructure facilities like roads, shops, hotels, resorts, restaurants, transportation facilities etc. These provide many job opportunities to local people.

Nakajo (2017) pointed out that during the recent years a number of tourists from all regions of India, who have ever visited Uttarakhand State, has been growing rapidly. It is obvious that many tourists come from the North and South West regions of India. However, a huge amount of tourists comes from the greater Delhi metropolitan area. It is assumed that these visits constitute to utilization of leisure by the center class. With new development of hill resorts, Naukuchiatal has been the main recipient of the ever-increasing number of domestic tourists. Surrounded by tourism resources centered on the lake, Uttarakhand State has experienced growing development of lodging accommodations by local residents and hotel capital from inside and out of doors the state. Hence, a particular significant contribution to the local economy is often observed by both local residents and merchants within the region regarding employment at lodging accommodations, necessary services, and therefore the demand for materials. Mukherjee and Mazumder (2018) proved a robust hope for the destination marketers. As people are spending significant part of their earning in tourism, tourism market seems to be promising. At a similar time, it is an enormous challenge for marketing professional to draw in tourists by taking proper strategies. Since awareness of induced tourism is found to be poor in India (with specific relevance for Nainital District), there is an outsized scope to push induced tourism. This study shows that individuals with different demographic profiles are induced differently in making their travel decisions. Hence, it is recommended to consider demographic profiles of the potential tourists carefully, formulating marketing strategies towards induced tourism.

Jethi (2016) noticed that it is quite evident that global tourism sector is anticipated to grow worldwide creating economic benefit through its multiplier effect on Indian economy. In such a case, market-based sustainable tourism model through promotion of ec- otourism could act as 'development paradigm' and a significant engine of sustainable economic growth, which could help reducing problem of giant income disparity within the company. Currently ecotourism could be a highly unregulated market in India with its major challenge being lack of uniform definition. To introduce ecotourism in India a standardized national framework of ecotourism or a broader sustainable tourism strategy must be developed. Das and Chatterjee (2015) focused on the policy makers of ecotourism. Ecotourism aims at the conservation of natural resources through socio-economic development of the indigenous communities. The protected areas like wildlife sanctuaries and national parks are observed in remote areas where locals rely upon natural resources for their sustenance. The policy-makers must realize that a gun and guard approach is not an effective policy in restricting the dependency of people on natural resources. Although it may help in short run, but to achieve a long run objective it is crucial for conservation practices to maintain a balance between resource preservation and development of indigenous communities. Development of locals not only implies economic development, but also social and cultural development. The experiences of ecotourism in Bhitarkanika Wildlife Sanctuary (BKWS) reveal that as a replacement venture in BKWS, it is still in the nascent stage. Although it allows creation of employment opportunities for locals and is partly able to improve the standard of living, but in terms of social empowerment through community participation, community cohesion, infrastructure development and cultural awareness, better and rigorous policies must be devised.

\section{AIM AND OBJECTIVES}

The aim and objectives of the study are:

- Investigate the existing tourist trend in Nainital.

- Identify activities that promote local cultural, eco hubs and ecotourism.

- Identify potential areas for tourism development.

- Access and analyze the support of state and local government. 
- Make reasonable suggestions for sustainable tourism development.

\subsection{Need and potential of ecotourism in Nainital}

Abode of Gods and the home of Himalayas, Uttarakhand State is renowned for its natural beauty, refreshing air, small villages, towering mountain ranges, and eternal purity. Nainital is known for serenity and scenic beauty. It is one of the favorite spots for tourists from all around the world. Its charming beauty, ancient holy places, forest, valleys, abundance of adventure and trekking options have made it as a prominent destination for tourists. Nainital, also known as the Lake City and Lake District of Uttarakhand State, is located around the Naini Lake. This place is named after the Goddess Naini Devi, the presiding idol of the area. It is located an altitude of $1,938 \mathrm{mts}$. Nainital is set in a valley containing a pear-shaped lake, approximately two miles in circumference, and surrounded by mountains. It is definitely a heaven for all the adventure finders, as it is a famous tourist destination of India, attracting hundreds of both domestic and foreign tourists every year. Some of the important places in the district are Nainital City, Hanumangarhi, Haldwani, Kaladhungi, Ramnagar, Bhowali, Ramgarh, Mukteshwar, Bhimtal, Sattal and Naukuchiatal.

However, Nainital also faces an unsure future, near-stripped of its natural heritage, invaded by vested interests. Moreover, it is converting into concrete jungles. There is an urgent need to embrace conservation of natural resources and to conserve and cherish the value of local traditions, customs and cultural heritage.

Thus, ecotourism has a huge potential to attract tourist to the state without destroying or degrading the natural or cultural assets that the visitor has come to see. Additionally, it would also provide employment and business opportunities to trained individuals of the state. Accordingly, conservation management and tourism activities may provide equitable, social and cultural benefits to men and women of Nainital local community through education, training and creation of full time employment opportunities. Further, ecotourism experiences also tend to be at the cutting edge of creativity in the tourism industry, and can be readily marketed to the ever-increasing numbers of people who wish to ensure that their holiday creates positive benefits, both for the environment and the local communities visited.

\subsection{Relevance of the study}

Many tourists now prefer visiting relatively undisturbed natural areas in order to enjoy and appreciate nature. Further, it has been noticed that such a tourism has contributed to the degradation of many areas of natural and cultural significance, entailing the loss of biological and cultural diversity, as well as the important sources of income. Therefore, this study will help protecting natural areas through the generation of revenues and the participation of local people of Nainital.

\section{METHODS}

Data has been collected from primary and secondary sources. Sampling technique for the project was the convenience sampling technique. Sample included 30 respondents (tourists) arrived at Nainital in March. Percentage method and descriptive statistical tools have been used. Data collection techniques such as structured interview schedule and questionnaire were used. Two tools were developed for this study, which are questionnaire (Appendix B) and a set of key questions (Appendix C) for the interview. Open-ended interview method was used to collect primary data. Secondary data was taken from journals, books and research papers. The information was gathered primarily by the information gained from interview with the chief executives, senior managers, mangers and other staff of the organizations viz. Hotels-Vikram Vintage, TRC-KMVN and Mannu Maharani, Boating Club, Uttarakhand Academy of Administration (ATI), Department of Tourism, Kumaun University, KMVN, Nainital, Uttarakhand Tourist Department, Mall road, State Guest House, Uttarakhand, Nagarpalika, Nainital.

In total, 10 people were interviewed to collect the opinions and views on the subject.

Responses collected from tourists using questionnaire were coded and entered into SPSS version 
20.0, which provided the data management requirements of the group project. Univariate analysis was performed on all the questions to provide descriptive frequencies.

\section{RESULTS AND DISCUSSIONS}

\subsection{Findings}

As per the response collected through interviews and discussions, the following findings are listed below.

\subsubsection{Activities undertaken to promote ecotourism in Nainital}

Following are the activities were undertaken to promote ecotourism at Nainital. However, Kumaon Mandal Vikas Nigam (KMVN) is conducting few ecotourism activities in form of eco-package tours and camps in adjoining areas of Nainital at Sigri and Dhikoli. Only one local fair titled 'Autumn' is organized at Nainital for promoting local culture.

\subsubsection{Need and potential of ecotourism in conserving natural and cultural diversity of Nainital}

There is a tremendous scope and potential of ecotourism in conserving nature and cultural diversity of Nainital. Potential of ecotourism is traced in form of bird watching, botanical gardens, village tourism, cultural tourism and rain water harvesting.

Due to the establishment of High Court at Nainital, many commercialized and illegal constructions are noticed, which have affected Nainital flora and fauna.

\subsubsection{Availability and accessibility of eco-hubs in Nainital and adjoining areas}

Only one eco-hub is available and accessible at Sigri. However, Pangoot, Sigri, Dhikoli, Sattal, Khurpataal, Magoli, Bajun, Ramgarh, Gurney House and Dorthy's Seat may be considered for developing additional eco-hubs at Nainital.

\subsubsection{Impact of eco and rural tourism on local capacity building and sustainable development}

Village tourism can be promoted, which at the same time popularize local cuisine. Promoting ecotourism would give positive impact on the financial and social status of the local community. Creation of traditional homes, local markets in eco-hubs would be an income generating activities. Further, interactive craft workshops overnight stay at the local styled guesthouse in eco-zone would definitely result in earning extra income by the local community. Ecotourism would create additional employment places for local people in terms of eco tour guides, sales assistants, care takers, cooks and drivers. Local community foresees ecotourism as opportunity for livelihood enhancement.

\subsubsection{Activities for promoting local culture in eco-hubs and eco-tours}

Nanda Devi Mahotsav, Shardostav, Autumn are few of the programs, which are organized at Nainital. However, the following activities form a major cultural background of the local people. These are kumaoni folk dances, lokgeets, music, arts and crafts, cuisine and life style.

\subsubsection{Availability of local cuisine (Kumauni) for tourists}

Local cuisine is not served anywhere except in KMVN's Tourist Rest houses. In cultural programmes like Ramlila, Falgun Utsav, Nanda Devi Mahostav etc., local food of Nainital can be promoted.

\subsubsection{Support of state and local governments in ecotourism ventures through ordinances and resolutions}

Ministry of tourism provides grants for promoting ecotourism and rural tourism in India. Under the Centrally Sponsored Scheme of Product / Infrastructure Development for Destinations and Circuits, 100\% Central Assistance is given for development of destinations/ circuits including mega projects to world standard, and also for rural tourism infrastructure development. However, the same has not been utilized properly for the development of Nainital eco-zone. 


\subsubsection{Conserve natural beauty}

Further, to conserve natural beauty, Nagapalika, Jheel Vikas Pradhikaran and Forest department have appointed lake wardens for cleanliness of lake. It was also reported that the fine is imposed on the use of plastic carry bags in Nainital by the civic bodies. However, a few stringent actions have been taken against those who are flouting the rules. Solid waste management and door-to-door collection of waste is also provided by the municipal authorities. At the same time, it is not strictly followed by local people and tourists.

\subsubsection{Opportunities of Nainital for promoting eco and rural tourism}

There are many cultural and heritage villages surrounding Nainital, which can attract ecotourists. Kilburi Forest area has an immense potential to be declared as world heritage, which may also attract interest of tourists. Tourism activities such as bird watching, adventure sports, health spa etc. may be developed for promoting Nainital eco and rural tourism.

\subsubsection{Impact of eco and rural tourism on income generation}

There would be positive impact of promoting ecotourism on income generation of the local community. In eco-hubs, local people may be invited to collaborate for promoting local handicrafts like, Ringal wood work, Pirul grass articles, Aipan art, thethun, artistic candles, etc.

Further, local people may also prepare and serve local dishes in eco-hubs and eco-villages, which will strengthen their financial status. Moreover, people from the local community may also be trained to find employment as guides, folk dancers and singers, yogacharya, etc.

\subsection{Suggestions}

Sound transportation facilities need to be established in Nainital. Air connectivity to the Kumaon Division needs to be strengthened, as people face tough time to reach this place. Tourists from all over the world flock to Nainital and improved connec- tivity would result in higher tourist inflows, which would attract more airlines to start operations.

Proper policy should be developed by the State Government for promoting ecotourism in the Kumaon Division. Pollution free vehicles should be made compulsory in Nainital. Kilburi can be declared a world heritage as silver fir trees are spread all over this place.

\subsection{Discussion}

Findings from the responses collected using questionnaire showed the following results. Over $96.7 \%$ tourists are aware of ecotourism. With little efforts $100 \%$ target can be achieved. Majority of tourists have enjoyed eco-holidays at different places. However, 27\% of the respondents have never spent any eco-holidays.

All male and female respondents realize the importance of benefits, which ecotourism can harbinger for Nainital. $43 \%$ of the respondents are extremely conscious about protection and conservation of the environment. However, $26.7 \%$ of the respondents are not particularly conscious about preserving flora and fauna.

Majority of the respondents agreed that there is tremendous tourist appeal of the local culture of Kumaon. However, the same needs to be introduced to the tourists.

$73 \%$ of the male respondents and $57 \%$ of the female respondents realizes the need for establishing eco-villages for attracting tourist to Nainital. However, $26 \%$ of the male respondents and $43 \%$ of the female respondents didn't find it relevant.

$91 \%$ of the male respondents and $85 \%$ of the female respondents admitted that they dispose waste material at the proper place and hence they depict eco-friendly attitude at Nainital. However, it was found that there should be a strict rule against littering by the tourists in Nainital and its surrounding areas.

There was a mixed response for the questions pertaining to the reason of visiting Nainital. Majority of tourist have shared that they have come for relaxation, and to experience natural beauty of the 
place. All the male and female respondents are interested in preserving and enhancing Nainital natural beauty.

\subsection{Problems in promoting ecotourism in Nainital}

It was estimated that the following problems must be solved: 1. Lack of appropriate government policies for promoting eco-tourism; 2. Transport and communications network are fragmented and costly; 3. Litter at the surrounding areas of Nainital is a hiccup in promoting ecotourism; 4. Haphazard transportation in the city causes a lot of inconvenience to local community, as well as to tourist plying to Nainital; 5. Lack of funds with the local people is a big challenge in promoting ecotourism; 6. Inactive participation of local community; 7. Selling of land and cottages by the local people to the outside people for commercial use.

\subsection{Suggestions for promoting ecotourism in Nainital}

Medicinal plants may be cultivated at the adjoining places like Jeolikote, Bhumiyadhar, Naini, Bajun, Khurpataal for enriching flora and fauna of the region. Remote areas of Nainital may be considered for developing eco-hubs and ethnic villages. This remoteness, and the pristine nature of the surroundings, should be heavily emphasized when promoting ecotourism in Nainital.

There should be strict ban on the construction of commercial buildings in Nainital in a bid to substantially enhance green cover. This will restrain Nainital in becoming concrete jungles. The financial institutions, particularly Nainital Cooperative Bank, should provide loans to the local people in building eco-hubs and villages at the surrounding places of Nainital. The Government should give support in form of subsidies, rebate, and reduction in taxes to community for promoting eco-hubs and villages at Nainital.

There is a tremendous and urgent need for publicity of tourist places at Nainital. Medical tourism and health tourism should also be promoted in Nainital, which may not only include modern medicine, but also indigenous health care traditions like Ayurveda, Siddha, Unani, Homeopathy, Naturopathy. Yoga may also be promoted. Zero emission vehicles shall be operated from Jelokote, Kaladungi and Bhimtal to Nainital. This will reduce carbon emission in the transportation and thereby will help in protecting biodiversity. The same has been implemented at the hill station Matheran in district Raigarh of Maharashtra.

Ethnic villages Chokidhani, Osian Village and Sandalwood of Rajasthan can be developed in the adjoining areas of Nainital, which shall act as the guardians of the local culture of the Kumaon Division. Local and traditional handicrafts, literature, and cuisine should be promoted along with the ecotourism activities. Gurni house and Dorthy's Seat shall be promoted to attract foreign tourists in Nainital. An ecotourism cell should be established to coordinate and monitor ecotourism activities in the Kumaon Division.

Visitor's center can be created to meet visitors needs or to provide tourists with information, other services and amenities. Community participation in the decision making process of tourism development will ensure sustainability and acceptability of tourism in Nainital. Before developing a policy for ecotourism, there shall be a comprehensive and detailed study of the local environment where eco-hub needs to be developed. Consortium of hotels may be developed for promoting ecotourism in the city.

State Government can develop ecotourism projects under public private partnership mode. Ecomuseum should be established at Nainital to preserve some old artistic work that the local people have done. This will give mythological insight into the values and ancient traditions of the place. Carrying capacity for the identified eco-hubs and for Nainital should be specified. A rigorous awareness campaign should be intensified to target tourists to help stimulate ecotourism. This will increase domestic arrivals at the destination leading to increase in revenue in the community.

Litter reduces the aesthetic appeal of a city. It poses environmental, health and safety concerns, too. Therefore, litter reduction and prevention program should be strictly adopted to preserve pristine beauty of Nainital and adjoining areas. Training to the host community shall be imparted, as they shall act as the managers of the ecotourism in the area. 


\section{CONCLUSION}

Thus, the study revealed that there is a tremendous potential of ecotourism at Nainital. It was noticed that Nainital is enriched with the beautiful, valuable and important landscape, but there is a lack of proper awareness among the public and tourists. Therefore, there is a need for developing an ecotourism center. Further, local communities, private sector enterprises, NGOs, local authorities and protected areas, State and Central Government along with the International bodies can act as a change agent in promoting ecotourism in Nainital. Thus, ecotourism can be used as a strategic tool for enhancing income generation of the local community with the true intention of conserving biodiversity.

\section{REFERENCES}

1. Aftabuddin, S. K., \& Kadambari, J. (2017). Green tourism practices in India - a paradigm shift in sustainable development. International Journal of Science Technology and Management, 6(5), 70-74. Retrieved from http:// www.ijstm.com/images/short pdf/1493821086_PY2055ijstm.pdf

2. Chopra, R. (2014). Uttarakhand: Development and ecological sustainability. Oxfam. Retrieved from https://www.oxfamindia.org/ sites/default/files/WP8UttarakhandDevpEcoSustainabiit3.pdf

3. Deshpande, B. K., \& Deshpande, R. (2016). A Study on Development of Tourism in $\mathrm{n}$ Maharashtra. International Journal of Scientific and Research Publications, 6(7), 175-181. Retrieved from http://www.ijsrp. org/research-paper-0716/ijsrpp5529.pdf

4. Goodwin, R. D., \& Chaudhary, S. K. (2017). Eco-Tourism dimensions and directions in India: An empirical study of Andhra Pradesh. Journal of Commerce and Management Thought, 8(3), 436-451. http:// dx.doi.org/10.5958/0976478X.2017.00026.X

5. Hameed, B., \& Khalid, A. (2018). Impact of Ecotourism in Ensuring the Sustainable Development of Tourism Industry in India. International Journal of Recent Research Aspects, 5(2), 46-50. Retrieved from http://www.ijrra. net/Vol5issue2/IJRRA-05-02-11. pdf

6. Jaiswal, B., \& Bisht M. (2017). Tourism Sector in Uttarakhand:
A brief Overview after the State Formation. International Journal of Research in Economics and Social Sciences (IJRESS), 7(7), 277-295. Retrieved from http://euroasiapub.org/wp-content/uploads /2017/08/29ESSJuly-5318-1.pdf

7. Jethi, V. (2016). Problems and Potential of Ecotourism Business in India. Advances in Economics and Business Management (AEBM), 3(8), 824-829.

8. Lad, D. G. (2013). Ecotourism Development in the Konkan Region of Maharashtra: A Review. Scholars Academic Journal of Biosciences, 1(6), 251-252. Retrieved from http:// saspublisher.com/wp-content/ uploads/2013/11/SAJB-16251-252. pdf

9. Lodi, S. (2013). Development of adventure tourism in Northern India: a case study of Uttrakhand (Doctoral Thesis). Aligarh Muslim University. Retrieved from http:// hdl.handle.net/10603/183809

10. Das, M., \& Chatterjee, B. (2015). Ecotourism and Empowerment: A Case Analysis of Bhitarkanika Wildlife Sanctuary, Odisha, India. IIM Kozhikode Society \& Management Review, 4(2), 136-145. https://doi.org/ 10.1177\%2F2277975215613175

11. Magray, N. A. (2018). Ecotourism: an adversity in itself with special reference to Jammu \& Kashmir. International Journal of Global Science Research, 5(2), 751-760. Retrieved from https://ijgsr.com/ webadmin/uploads/102\%20 ijgsr\%20NASEER\%20 AHMAD\%20MAGRAY.pdf
12. Mukherjee, T., \& Mazumder, A. (2018). An Empirical Study on Induced Tourism in Nainital Town. IOSR Journal of Business and Management, 28-35. Retrieved from http://iosrjournals. org/iosr-jbm/papers/Conf.1802 2018/Volume-3/Innovation\%20 in\%20Mangement/4.\%2028-35. pdf

13. Murphy, P. E., \& Price, G. G. (2005). Tourism and sustainable development. In W. Theobald (Ed.), Global Tourism, (pp. 167193). Elsevier Inc. Retrieved from https://www.economy.gov.ae/Publications/Butterworth-Heinemann. Global.Tourism.ISBN0750677899. pdf

14. Nag, A. (2018). A study of Tourism industry of Himachal Pradesh with Special Reference to Ecotourism. SUMEDHA Journal of Management, 7(1), 85-106. Retrieved from http:// cmrcetmba.in/SUMEDHA_ADMIN/journal_attachment/1548143835_352527092.pdf

15. Nakajo, A. (2017). Development of tourism and the tourist industry in India: A case study of Uttarakhand. Journal of Urban and Regional Studies on Contemporary India, 3(2), 1-12. https://doi.org/10.15027/43726

16. Navare, P., \& Mali, S. (2015). Ecotourism in Maharashtra's Konkan region - the way to sustainable development. AbhinavInternational Monthly Refereed Journal of Research in Management \& Technology, 4(11), 1-5. Retrieved from https://www.semanticscholar. org/paper/ECO-TOURISM-IN- 
MAHARASHTRA\%E2\%80\%99SKONKAN-REGION-THE-Navare -Mali/484f1311aabf08fd66f8f4bb6 $68 \mathrm{e} 16 \mathrm{~b} 439 \mathrm{e} 5 \mathrm{ce} 9 \mathrm{c}$

17. Patel, P. (2020). A study on ecotourism and its sustainability in India (Project report). GLS University. http://dx.doi. org/10.13140/RG.2.2.18651.80160

18. Poyyamoli, G. (2018). Ecotourism policy in India: Rhetoric and reality. Grassroots Journal of Natural Resources, 1(1), 4661. https://doi.org/10.33002/ nr2581.6853.01015

19. Ramamoorthi, D, \& Udaya, K. (2019). A Study on Impact of Tourism and Sustainable Measures in OOTY, the Nilgiris. IOSR Journal of Business and Management (IOSR-JBM), 21(4), 34-41. Retrieved from http:// iosrjournals.org/iosr-jbm/ papers/Vol21-issue4/Series-5/ E2104053441.pdf

20. Robinson, D. W. (1992). Sociocultural impacts of mountain tourism on Nepal's Sagarmatha (Everest) world heritage site: implications for sustainable tourism. IUCN.

21. Saraswati, A. K., \& Ram, P. (2017). Hill tourism and sustainable development of the destinations: A situation analysis of Kumaon region of Uttarakhand. International Journal of Marketing \& Financial Management, 5(1), 7084. Retrieved from https://zenodo. org/record/259324\#.YJPbqbUzaUk

22. Sati, P. V. (2013). Tourism practices and approaches for its development in the Uttarakhand Himalaya, India. Journal of Tourism Challenges and Trends, 6(1), 97-111. Retrieved from https://www.semanticscholar.org/ paper/Tourism-practices-andapproaches-for-its-in-the-Sati/6b e17aad9a694cbb7ac0b7aa5a53781 fd1060449

23. Sharpley, R. (2000). Tourism and sustainable development: Exploring the theoretical divide. Journal of Sustainable Tourism, 8(1), 1-19. https://doi. org/10.1080/09669580008667346
24. Singh, J. J., \& Munjal, S. (2015). Sustainable Eco-Tourism: A Case Study from India. In Environmental Conservation and Sustainable Development (pp. 102-117). Delhi: Lenin Media. Retrieved from https://papers.ssrn. com/sol3/papers.cfm?abstract $\mathrm{id}=2776908$

25. Singh, M. (2018). Sustainable development of tourism in Uttarakhand (India). International Journal of Academic Research and Development, 3(2), 828831. Retrieved from http://www. academicjournal.in/archives/2018/ vol3/issue2/3-2-206

26. Singh, R. (2016). Eco-Tourism and Sustainable Development. International Journal of Research in Humanities \& Soc. Sciences, 4(4), 51-55. Retrieved from http://www.raijmr.com/ijrhs/ wp-content/uploads/2017/11/ IJRHS_2016_vol04_issue_04_09. pdf

27. Singh, V., \& Kotru, R. (2018). Report of Working Group II: Sustainable Tourism in the Indian Himalayan Region. New Delhi: NITI Aayog. Retrieved from https://www.niti.gov.in/writereaddata/files/document_publication/ Doc2.pdf

28. State of Uttarakhand. (2014). Infrastructure Development Investment Program for Tourism (Tranche 3). Conservation of Cultural Heritage and Urban Placemaking in Nainital. Draft Initial Environmental Examination. Retrieved from https://www.adb.org/ sites/default/files/projectdocument/148728/40648 034-iee-23.pdf

29. Tamta, A. K. (2016). Impact of seasonality in tourism and sustainable development (a study of Nainital town). Scholarly Research Journal for Interdisciplinary Studies, 4(27), 3380-3389. Retrieved from http://www.srjis.com/pages/pdfFiles/148611399341.Anil\%20 Kumar\%20Tamta.pdf

30. Tripathi, U. N., \& Jain, A. K. (2017). Opportunities and challenges of ecotourism with reference to its employability potential: Uttar Pradesh, India. Scholarly Research Journal for Interdisciplinary Studies, 4(37), 8872-8882. Retrieved from http://oaji.net/articles/2017/1174-1522065418.pdf

31. Venkatesh, M., \& Raj, D. J. (2016). Impact of tourism in India. International Journal of Scientific Engineering and Applied Science, 2(1), 167-184. Retrieved from http://ijseas.com/volume2/v2i1/ ijseas20160119.pdf 


\section{APPENDIX A}

Awareness about eco-tourism

$95.7 \%$
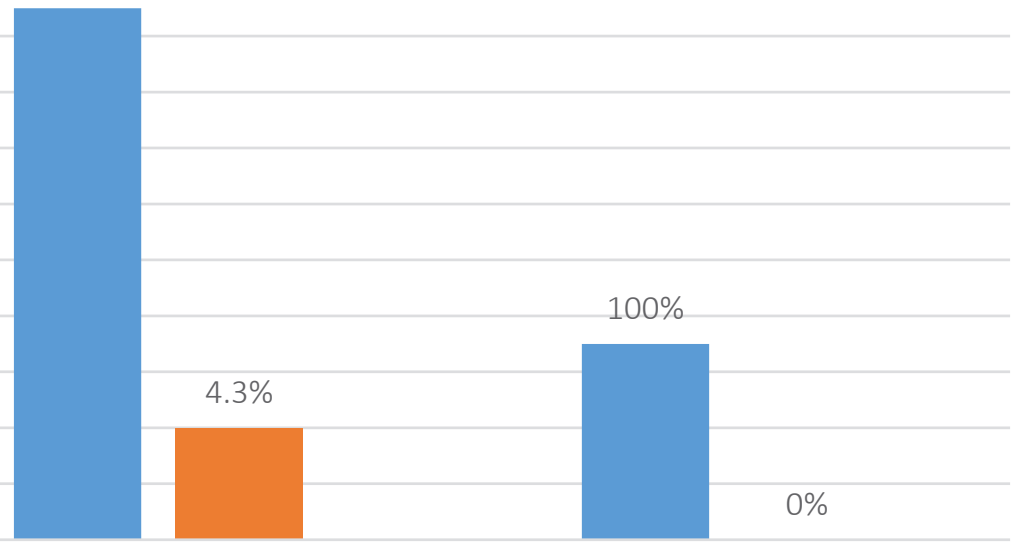

Female

Figure A1. Awareness about eco-tourism

Conscious about protection and conservation of the enviroment

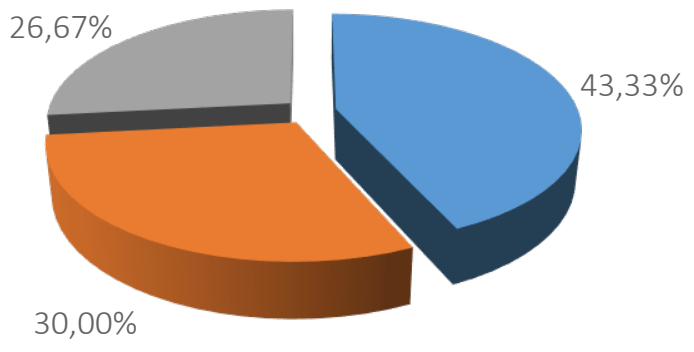

Very much

- Quite a lot

A little

Figure A2. Protection and conservation of the environment

Table A1. Ecotourist holiday

\begin{tabular}{|c|c|c|c|c|c|}
\hline \multicolumn{2}{|c|}{ Gone for holiday } & \multirow{2}{*}{$\frac{\text { Frequency }}{22}$} & \multirow{2}{*}{$\frac{\text { Percent }}{73.3}$} & \multirow{2}{*}{$\begin{array}{c}\text { Valid percent } \\
73.3\end{array}$} & \multirow{2}{*}{$\begin{array}{c}\text { Cumulative percent } \\
73.3\end{array}$} \\
\hline \multirow{3}{*}{ Valid } & Yes & & & & \\
\hline & No & 8 & 26.7 & 26.7 & 100.0 \\
\hline & Total & 30 & 100.0 & 100.0 & - \\
\hline
\end{tabular}

Table A2. Benefits from ecotourism activities

\begin{tabular}{|c|c|c|c|c|c|c|}
\hline \multicolumn{3}{|c|}{ Gender } & \multirow{2}{*}{$\frac{\text { Frequency }}{23}$} & \multirow{2}{*}{$\frac{\text { Percent }}{100.0}$} & \multirow{2}{*}{$\frac{\text { Valid percent }}{100.0}$} & \multirow{2}{*}{$\frac{\text { Cumulative percent }}{100.0}$} \\
\hline Male & Valid & Yes & & & & \\
\hline Female & Valid & Yes & 7 & 100.0 & 100.0 & 100.0 \\
\hline
\end{tabular}

Table A3. Tremendous tourist appeal about local culture

\begin{tabular}{|c|c|c|c|c|c|}
\hline \multicolumn{2}{|c|}{ Tremendous tourist appeal } & \multirow{2}{*}{$\frac{\text { Frequency }}{26}$} & \multirow{2}{*}{ Percent } & \multirow{2}{*}{$\frac{\text { Valid percent }}{86.7}$} & \multirow{2}{*}{$\frac{\text { Cumulative percent }}{86.7}$} \\
\hline \multirow{3}{*}{ Valid } & Yes & & & & \\
\hline & No & 4 & 13.3 & 13.3 & 100.0 \\
\hline & Total & 30 & 100.0 & 100.0 & - \\
\hline
\end{tabular}


Table A4. Establishing eco villages or ethnic villages for tourists in Nainital

\begin{tabular}{|c|c|c|c|c|c|c|}
\hline \multicolumn{3}{|c|}{ Gender } & Frequency & Percent & Valid percent & Cumulative percent \\
\hline \multirow{3}{*}{ Male } & \multirow{3}{*}{ Valid } & Yes & 17 & 73.9 & 73.9 & 73.9 \\
\hline & & No & 6 & 26.1 & 26.1 & 100.0 \\
\hline & & Total & 23 & 100.0 & 100.0 & - \\
\hline \multirow{3}{*}{ Female } & \multirow{3}{*}{ Valid } & Yes & 4 & 57.1 & 57.1 & 57.1 \\
\hline & & No & 3 & 42.9 & 42.9 & 100.0 \\
\hline & & Total & 7 & 100.0 & 100.0 & - \\
\hline
\end{tabular}

Table A5. Disposing waste material in the proper place in Nainital

\begin{tabular}{|c|c|c|c|c|c|c|}
\hline & Gender & & Frequency & Percent & Valid percent & Cumulative percent \\
\hline \multirow{3}{*}{ Male } & \multirow{3}{*}{ Valid } & Yes & 21 & 91.3 & 91.3 & 91.3 \\
\hline & & No & 2 & 8.7 & 8.7 & 100.0 \\
\hline & & Total & 23 & 100.0 & 100.0 & - \\
\hline \multirow{3}{*}{ Female } & \multirow{3}{*}{ Valid } & Yes & 6 & 85.7 & 85.7 & 85.7 \\
\hline & & No & 1 & 14.3 & 14.3 & 100.0 \\
\hline & & Total & 7 & 100.0 & 100.0 & - \\
\hline
\end{tabular}

Table A6. Preserving and enhancing natural beauty in Nainital

\begin{tabular}{|c|c|c|c|c|c|c|}
\hline \multicolumn{3}{|c|}{ Gender } & \multirow{2}{*}{$\frac{\text { Frequency }}{23}$} & \multirow{2}{*}{$\frac{\text { Percent }}{100.0}$} & \multirow{2}{*}{$\begin{array}{c}\text { Valid percent } \\
100.0\end{array}$} & \multirow{2}{*}{$\begin{array}{c}\text { Cumulative percent } \\
100.0\end{array}$} \\
\hline Male & Valid & Yes & & & & \\
\hline Female & Valid & Yes & 7 & 100.0 & 100.0 & 100.0 \\
\hline
\end{tabular}

\section{APPENDIX B}

\section{Questionnaire for eco-tourism providers}

To be gathered from Hotels, KMVN, Tourism Development Board and Boating club

Name

Designation

Organization

\begin{tabular}{|c|c|c|}
\hline S. No. & Key questions & Response \\
\hline 1. & Activities undertaken to promote Eco-tourism in Nainital & \\
\hline 2. & Need and Potential of eco-tourism in conserving natural and cultural diversity of Nainital & \\
\hline 3. & Availability and Accessibility of eco-hubs in Nainital and adjoining area & \\
\hline 4. & Impact of eco and rural tourism on local capacity building and sustainable development & \\
\hline 5. & Activities for promoting local culture in eco-hubs and eco-tours & \\
\hline 6. & Availability of local cuisine (Kumauni) for tourists & \\
\hline 7. & Support of State and local government in eco-tourism ventures through ordinances and resolutions & \\
\hline 8. & Opportunities in Nainital for promoting Eco-tourism and rural tourism & \\
\hline 9. & Impact of Eco-tourism and rural tourism on income generation & \\
\hline 10. & Suggestions to promote eco-tourism and rural tourism in the Nainital City & \\
\hline
\end{tabular}




\section{APPENDIX C}

\section{Questionnaire to be filled by Tourists in Nainital}

नैनीताल में पर्यटक द्वारा भरे जाने के लिए प्रश्नावली

Name नाम

Gender लिंग (Male/Female) (पुरूष/महिला)

Age आयु

Place स्थान

Q1. Are you aware about eco-tourism?

क्या आपको पर्यावरणीय पर्यटन के बारे में ज्ञात है ?

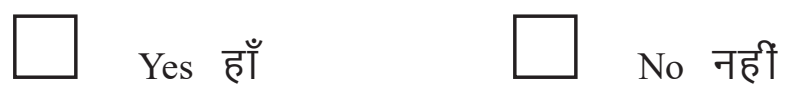

Q2. Have you ever gone for an eco-tourist holiday?

क्या आप कभी पर्यावरणीय पर्यटन अवकाश पर गए हैं ?

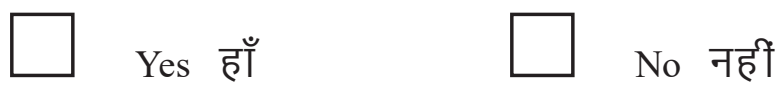

If yes, then at which place

यदि हां, तो किस स्थान पर

Q3. Do you think that you will be benefited with the ecotourism activities?

क्या आप सोचते हैं कि आप पर्यावरणीय पर्यटन के लिए सहायक सिद्ध हो सकते हैं ?

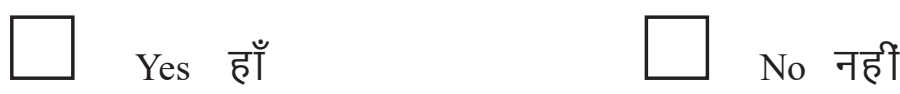

Q4. Do you think that you are conscious about protection, conservation and development of environment? क्या आप सोचते हैं कि आप पर्यावरणीय पर्यटन के बचाव, संरक्षण एवं विकास के लिए सजग है ?

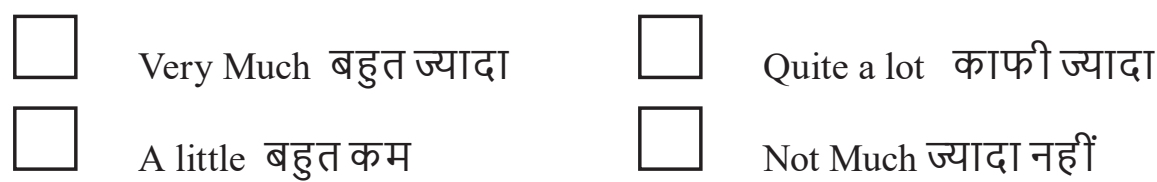

Q5. Did you find any eco-tourism activity at Nainital?

क्या आपको नैनीताल में कोई पर्यावरणीय पर्यटन सम्बन्धी गतिविधियां दिखी हैं ?

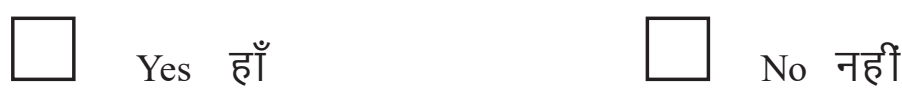

If yes then specify that activity

यदि हैं तो स्पष्ट कीजिए

Q6. Do you think that local culture of Nainital (Kumaun) has a tremendous tourist appeal? क्या आप सोचते हैं कि कुमाऊँ की स्थानीय संस्कृति पर्यटकों को प्रभावित करेगी ?

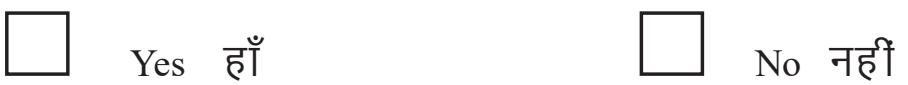


Q7. Do you think that there is a need for establishing eco-villages or ethnic villages for tourists in Nainital? क्या आप सोचते हैं कि नैनीताल में पर्यटकों के लिए पर्यावरणीय तथा पारम्परिक गाँवों की आवश्यकता है?

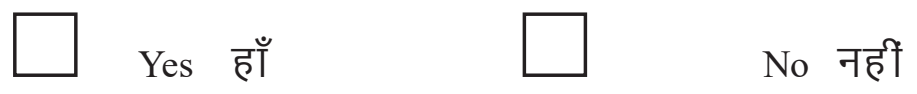

Q8. Which of the following is/are the reasons of your visit to Nainital?

निम्न में से कौन-सा कारण से आप नैनीताल घूमने आये हैं ?

- Relaxation and change आराम तथा बदलाव

- Shopping खरीददारी

- Adventure activities एडवेंचर गतिविधियां

- Experiencing Local Culture स्थानीय संस्कृति तथा अनुभव

- Experience Nature and beauty scenery प्राकृतिक सुन्दरता का अनुभव

- Expedition activities साहसिक अभियान

- Bird Watching पक्षियों को देखना

- Taking part in annual festivities वार्षिक उत्सव में भाग लेने

- Others अन्य

Q9. Are you disposing waste material in the proper place at Nainital? क्या आप अपशिष्ट पदार्थ/ बेकार सामग्री को नैनीताल में नियत स्थानों पर फेंकते हैं?

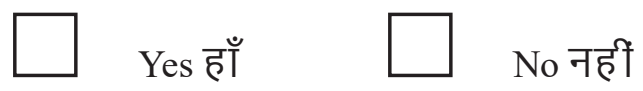

Q10. Can you contribute to preserving and enhancing natural beauty in Nainital? क्या आप नैनीताल की सुन्दरता को अक्षुण्ण रखने के लिए सहयोग दे सकते हैं ?

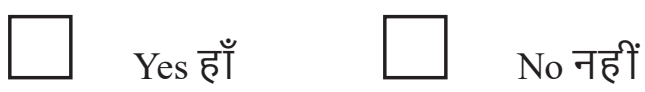

